\title{
Correlation of SPECT imaging, biochemical parameters and mutation with systolic dysfunction
}

D. Alenizi' ${ }^{1}$, N.A. Kizilbash ${ }^{2}$, O. Gill ${ }^{3}$, A. Abukanna ${ }^{1}$, S. Malik ${ }^{4}$ and

A. Badawy

${ }^{1}$ Department of Medicine, Faculty of Medicine, Northern Border University, Arar, Saudi Arabia

${ }^{2}$ Department of Biochemistry, Faculty of Medicine, Northern Border University, Arar, Saudi Arabia

${ }^{3}$ Punjab Institute of Nuclear Medicine, Faisalabad, Pakistan

${ }^{4}$ Department of Animal Sciences, Faculty of Biological Sciences,

Quaid-i-Azam University, Islamabad, Pakistan

${ }^{5}$ Department of Medical Biochemistry, Faculty of Medicine,

Mansoura University, Mansoura, Egypt

Corresponding author: N. Kizilbash

E-mail: nadeem_kizilbash@yahoo.com

Genet. Mol. Res. 12 (4): 5964-5977 (2013)

Received November 21, 2012

Accepted August 8, 2013

Published November 26, 2013

DOI http://dx.doi.org/10.4238/2013.November.26.6

ABSTRACT. We investigated systolic dysfunction by the use of biochemical laboratory tests and perfusion single-photon emission computed tomography imaging in 32 Pakistani subjects exhibiting symptoms of this disorder. To investigate underlying genetic causes, such as familial hypercholesterolemia, DNA samples from these subjects were screened by PCR-SSCP and DNA sequencing to detect changes in the low density lipoprotein receptor gene $(L D L R)$. A novel mutation $(1171 \mathrm{G}>\mathrm{A})$ in exon 8 and two polymorphisms $(1167 \mathrm{G}>\mathrm{A}$ and $1413 \mathrm{~A}>\mathrm{G}$ ) in exons 8 and 10 of the $L D L R$ gene were found. In silico tools such as SIFT, PolyPhen-2, KD4v, and Project HOPE were used 
to predict the effect of this mutation on protein structure and function.

Key words: $L D L R$ gene polymorphism; Systolic dysfunction; LDL receptor; Familial hypercholesterolemia; SPECT

\section{INTRODUCTION}

The death rate due to coronary heart disease is $0.41 \%$ in Pakistan (Samad et al., 1992). According to the National Health Survey of Pakistan (NHSP), the rate of occurrence of hypertension among Pakistanis is $17.9 \%$, while it is $10 \%$ for diabetes and $13 \%$ for high blood cholesterol (Khan and Mallick, 1992). One of the factors required for development of coronary heart disease is atherosclerosis (Davignon and Ganz, 2004). Atherosclerosis is a condition in which an artery wall thickens as a result of the accumulation of fatty materials such as cholesterol. It is caused largely by the accumulation of macrophage white blood cells and promoted by low-density lipoproteins (LDL). Atherosclerosis is commonly referred to as hardening of the arteries and is caused by the formation of multiple plaques in arteries (Maton et al., 1993).

Normal functioning of low-density lipoprotein receptor (LDLR) is important for maintenance of normal levels of plasma LDL cholesterol (LDL-C). LDLR regulates the concentration of plasma LDL-C by receptor-mediated endocytosis. Mutations in $L D L R$ gene produce familial hypercholesterolemia (FH). The estimated prevalence of heterozygous $\mathrm{FH}$ is $0.2 \%(1: 500)$ in most populations of the world. Worldwide, an estimated ten million people are affected by FH. Patients with FH are characterized by a high plasma LDL-C starting in early childhood, tendon xanthomas and an increased risk of premature coronary artery disease (Austin et al., 2004).

LDLR is a cell-surface receptor that recognizes apoB100 protein in the phospholipid outer layer of LDL particles (Figure 1). It mediates the endocytosis of cholesterol-rich LDL. The receptor also recognizes apoE protein found in chylomicron remnants and very low density lipoprotein remnants (intermediate density lipoprotein). The can be regarded as a chimeric protein. It is made up of a number of domains that can function independently of each other (Yamamoto et al., 1984).

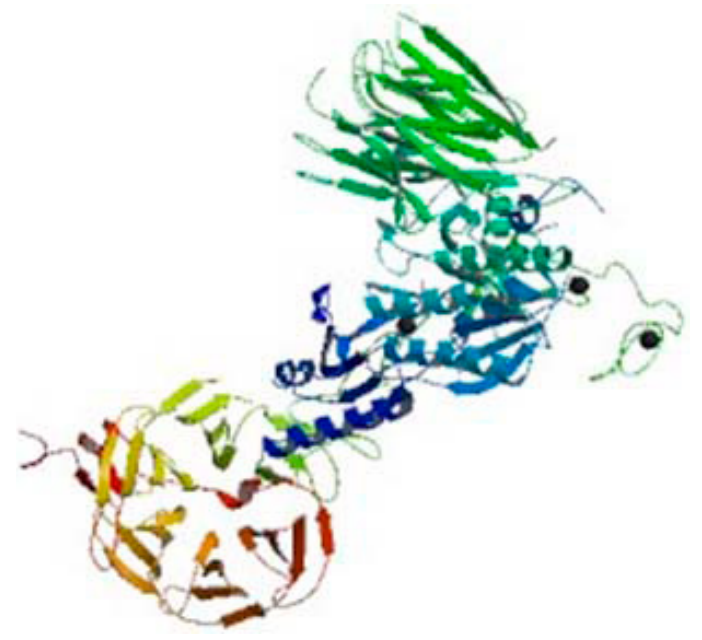

Figure 1. X-ray crystal structure of low density lipoprotein receptor in complex with PCSK9 (PDB-file: 3m0c). 
In humans, the LDL receptor protein is encoded by the $L D L R$ gene (Francke et al., 1984; Lindgren et al., 1985). LDLR gene is located on the short arm of chromosome 19. It comprises 18 exons and spans $45 \mathrm{~kb}$. Exon 1 contains a signal sequence that localizes the receptor to the endoplasmic reticulum for transport to the cell surface. Exons 2-6 code for the ligand-binding region; exons 7-14 code for the EGFP domain; exon 15 codes for the oligosaccharide-rich region; exon 16 (and some of exon 17) code for the membrane-spanning region; and exon 18 (along with the rest of exon 17) code for the cytosolic domain. A single abnormal copy of $L D L R$ gene (heterozygote) causes cardiovascular disease by the age of 50 in about $40 \%$ of cases. Having two abnormal copies (homozygote) causes accelerated atherosclerosis in childhood, including its complications. Plasma LDL levels are inversely related to the activity of LDLR. Homozygotes have less than $2 \%$ LDLR activity, while heterozygotes have defective LDL processing with receptor activity being $2-25 \%$, depending on the nature of the mutation. Five major classes of FH are known (Hobbs et al., 1992):

Class I: LDLR is not synthesized in cells.

Class II: LDLR is not transported from the endoplasmic reticulum to the Golgi apparatus and ultimately does not reach the cell surface.

Class III: LDLR does not bind LDL on the surface of cells due to a defect in either apolipoprotein B100 (R3500Q mutation) or in LDL-R.

Class IV: LDLR binds LDL but does not undergo receptor-mediated endocytosis.

Class V: LDLR is not recycled back to the cell surface.

Exactly, 1741 different mutations in the LDLR gene are known. More than 150 mutations have been characterized at the molecular level (Hobbs et al., 1992; Hobbs et al., 1992). Mutations in $L D L R$ gene cause the autosomal dominant inherited disorder $\mathrm{FH}$, which is characterized by a high plasma cholesterol level, tendon xanthoma (Tsouli et al., 2005), and development of coronary artery disease. The frequency of homozygous FH is $1: 10^{6}$; and the frequency for heterozygous $\mathrm{FH}$ is 1:500, making heterozygous $\mathrm{FH}$ one of the most common serious genetic disorders (Goldstein et al., 1995).

In this project, we recruited 40 subjects (32 patients plus 8 controls) and evaluated their basic demographic characteristics and medical parameters using clinical chemistry tests. Twelve of the subjects also underwent stress/rest myocardial perfusion studies using SPECT imaging. DNA samples from all the subjects were screened for the five most common mutations in the LDLR gene. These mutations are: nonsense mutation W23X, missense mutations W66G and W556S, and splice-site mutations $313+1 \mathrm{G}>\mathrm{A}$ and $1846-1 \mathrm{G}>\mathrm{A}$ (Hobbs et al., 1992).

\section{MATERIAL AND METHODS}

\section{Patient selection}

This study comprised 32 subjects exhibiting systolic dysfunction. The subjects were recruited at the Punjab Institute of Nuclear Medicine (Faisalabad, Pakistan). Eight healthy adults with no systolic dysfunction were selected on a voluntary basis and comprised the control group. Hospital Ethics Committee approval was obtained. The screening of the subjects was according to age and sex, blood pressure level, obesity, family medical history, habitual tobacco smoking, hemostatic factors and presence of diabetes. The following criteria were used for patient selection. 
Criterion Description of patients:

a) Total cholesterol concentration above $7.5 \mathrm{mM}$ in adults or above $6.7 \mathrm{mM}$ in children under 16 years, or low density lipoprotein cholesterol concentration above 4.9 $\mathrm{mM}$ in adults or above $4.0 \mathrm{mM}$ in children;

b) Tendon xanthoma in the patient or a 2 nd degree relative;

c) DNA-based evidence of mutation in the $L D L R$ gene;

d) Family history of myocardial infarction before age 50 years in a 3 rd degree relative or before age 60 years in a 1st degree relative;

e) Family history of high total cholesterol concentration above $7.5 \mathrm{mM}$ in a $1 \mathrm{st}$ or 2nd degree relative.

All the experimental subjects selected belonged to the age group 15-35 years. A 500- $\mu \mathrm{L}$ blood sample was obtained from both the subjects and controls and stored in EDTA-coated vacutainers. All subjects were divided into three groups on the basis of serum LDL-cholesterol value. Group-I (control group): 8 subjects with normal serum cholesterol and LDL-C

Group-II: 20 subjects with high serum cholesterol or LDL-C but not in the range of FH Group-III: 12 subjects selected on the basis of high serum cholesterol $(>7.5 \mathrm{mM})$ or LDL-C $(>4.9 \mathrm{mM})$

\section{Measurement of total cholesterol}

The method for cholesterol measurement used hexane extraction after hydrolysis with alcoholic $\mathrm{KOH}$ followed by reaction with the Liebermann-Burchard color reagent, which contains sulfuric acid, acetic acid and acetic anhydride (Abel et al., 1952).

\section{Measurement of LDL-C}

The method for measuring LDL-C was the beta quantification method in which the beta designation refers to the electrophoretic term for LDL. Beta-quantification combines ultracentrifugation and chemical precipitation (Bachorik, 2000).

\section{Myocardial perfusion scintigraphy}

In SPECT imaging, a radioactive pharmaceutical product (a radionuclide) such as ${ }^{99 \mathrm{~m}} \mathrm{Tc}-\mathrm{MIBI}$, which decays with the emission of gamma rays, is injected in the patient. The principle of SPECT imaging is that under conditions of stress, diseased myocardium receives less blood than normal myocardium. A healthy tissue takes up a known amount of the radioactive pharmaceutical product and it appears as a bright area in the SPECT image. If a tissue is abnormal, the uptake of the radiopharmaceutical can be increased or decreased and it can appear as a more intense spot or a dark area, respectively, on the image. Such an image can be interpreted by a cardiologist as a suspected diseased state. Different processing algorithms allow a reproducible and reliable assessment of left ventricular (LV) function, which is validated against various references (Michelena and VanDecker, 2005).

SPECT imaging was performed on the 12 group-III subjects after induction of pharmacological stress. It revealed the distribution of the radiopharmaceutical, and therefore the 
relative blood flow to the different regions of the myocardium. Diagnosis was made by comparing stress images with a further set of images obtained at rest. Two sets of cardiac SPECT images were acquired for the twelve group-III subjects (serum cholesterol level $>7.5 \mathrm{mM}$ or LDL-C level $>4.9 \mathrm{mM}$ ) using a Siemens E.CAM Gamma Camera. On the first day, a resting cardiac scan was done by injecting $740 \mathrm{MBq}(20 \mathrm{mCi}){ }^{99 \mathrm{~m}} \mathrm{Tc}-\mathrm{MIBI}$, and imaging started after $35 \mathrm{~min}$. On the second day, cardiac stress scan was performed. All subjects underwent dual cardiac stress (pharmacological + physical) by injection of $740 \mathrm{MBq}(20 \mathrm{mCi}){ }^{99 \mathrm{~m}} \mathrm{Tc}-\mathrm{MIBI}$ at peak stress. The images were recorded after $35 \mathrm{~min}$.

\section{Mutational analysis}

The molecular biology part of the study consisted of screening the DNA of all the 32 patients for five common mutations (W23X, W66G, W556S, 313+1G $>$ A, and 1846-1G $>$ A) in the LDL receptor gene. The DNA samples were amplified by polymerase chain reaction (PCR) and screened for mutations by single strand conformational polymorphism (SSCP).

\section{Isolation of DNA}

Genomic DNA was extracted from blood using the Qiagen Mini Elute DNA extraction kit from $200 \mu \mathrm{L}$ whole blood. A 5- $\mu \mathrm{L}$ aliquot of genomic DNA was checked by agarose gel electrophoresis to confirm its quality. The remaining DNA was stored at $-40^{\circ} \mathrm{C}$ for further processing.

\section{DNA amplification}

DNA was amplified for all the exons and promoter region in a reaction mixture of 100 $\mu \mathrm{L}$ containing $3 \mu \mathrm{L} 20$ pmol primers, $50 \mu \mathrm{L}$ Gotaq Green Master mix and $15 \mu \mathrm{L}$ template. The remaining volume was made up with nuclease-free water. The amplified product was then checked by agarose gel electrophoresis before subjecting it to SSCP analysis.

To get efficient denaturation, both chemical and thermal denaturation was carried out. After a number of experiments, a universal denaturant mixture was prepared by mixing equal volumes of $100 \mathrm{mM} \mathrm{NaOH}$ and formamide loading buffer, which denatured all the 18 exons and promoter region quiet efficiently. The formamide loading buffer was prepared by mixing $10 \mathrm{~mL}$ formamide, $200 \mu \mathrm{L} 0.5 \mathrm{M}$ EDTA, $1.5 \mathrm{mg}$ xylene cyanol, and $3 \mathrm{mg}$ bromophenol blue. A volume of $10 \mu \mathrm{L}$ amplified PCR product was mixed with $10 \mu \mathrm{L}$ chemical denaturant and heat-denatured at $95^{\circ} \mathrm{C}$ for $7 \mathrm{~min}$. After denaturation, samples were placed on ice for $10 \mathrm{~min}$ to prevent re-annealing and to stop the adoption of a specific conformation.

\section{Screening DNA samples by SSCP}

The research subjects were then screened against the five common mutations in the $L D L R$ gene (W23X, W66G, W556S, 313+1G $>\mathrm{A}$, and $1846-1 \mathrm{G}>\mathrm{A}$ ) by using the primers and restriction enzymes described in Table 1 . These primers created a cleavage site in the presence of a specific mutation. Amplified products were digested with their respective enzymes as per protocol and separated by agarose gel electrophoresis. All samples were found negative for these known mutations. 


\begin{tabular}{|c|c|c|c|}
\hline Mutation & Primers & Restriction enzymes & Fragments after cleavage \\
\hline \multirow[t]{2}{*}{ W23X } & TTGAGAGACCCTTTCTCCTTTTCC & \multirow[t]{2}{*}{ Alul } & Norm: 118 bp \\
\hline & CAGCGCTGCCATCGCAGAGC & & Htz: $118+88$ bp \\
\hline \multirow[t]{2}{*}{ W66G } & TTCCTTTGAGTGACAGTTCAATCC & \multirow[t]{2}{*}{ Taq 1} & Norm: $130 \mathrm{bp}$ \\
\hline & GTCCACTTGGCCATCGCACCTCT & & Htz: $130+105 \mathrm{bp}$ \\
\hline \multirow[t]{2}{*}{ W556S } & TCAGGCCCTCTGGGACTGGC & \multirow[t]{2}{*}{$T a q 1$} & Norm: $114 \mathrm{bp}$ \\
\hline & CTTGAGATGGAGTGAAGTTTGGAGTCAATC & & Htz: $114+83$ bp \\
\hline \multirow{2}{*}{$313+\mathrm{IG}>\mathrm{A}$} & TTCCTTTGAGTGACAGTTCAATCC & \multirow[t]{2}{*}{ Ndel } & Norm: 190 bp \\
\hline & CTCAATAGCAAAGGCAGGGCCACACAT & & Htz: $190+164 \mathrm{bp}$ \\
\hline \multirow[t]{2}{*}{$1846-1 \mathrm{G}>\mathrm{A}$} & GTCATCTTCCTTGCTGCCTGTCTA & \multirow[t]{2}{*}{$D d e l$} & Norm: 217 bp \\
\hline & TTCCACAAGGAGGTTTCAAGGTTGGGGGGG & & Htz: $217+196 \mathrm{bp}$ \\
\hline
\end{tabular}

\section{Gel analysis by SSCP}

The composition of the acrylamide gel is a very important parameter for SSCP analysis. Glycerol added gels of various compositions were prepared. A series of experiments were carried out to adjust the composition of the gel for each exon. The gels were run in ice cold $1 \mathrm{X}$ TBE buffer at $16^{\circ} \mathrm{C}$ for various run times in a Bio-Rad Mini Protean Terta Cell.

\section{DNA sequencing}

A total of 12 reaction mixtures were sent for sequencing. DNA was amplified in 100 $\mu \mathrm{L}$ reaction mixture, purified and cleaved from the oligonucleotide with the help of the Qiagen PCR purification kit. The cleaved PCR products were sent to Eurofines (Canada) for sequencing.

\section{RESULTS}

\section{Laboratory tests}

All subjects and controls were required to provide a complete medical history and were given a thorough clinical examination. Mean systolic and diastolic blood pressure were measured according to a standardized protocol after at least 10 min rest using a validated automated machine and appropriate cuff. Blood samples from the subjects and controls were used for the estimation of total cholesterol and LDL-C.

Table 2 shows the characteristics of the subjects; age of patients ranged from 15 to 35 years. Serum levels of total cholesterol and LDL-C were not significantly higher in patients as compared to controls $(\mathrm{P}>0.05)$. There was also no significant difference in the presence of diabetes between the subjects and the controls $(\mathrm{P}>0.05)$. However, significant differences were found for presence of hypertension and smoking habit $(\mathrm{P}<0.001)$ between subjects and controls.

\section{Myocardial perfusion scintigraphy}

Single photon emission computed tomography scans were done on 12 patients to check for evidence of coronary artery disease and to assess left ventricular function. Seven patients were found to have extensive ischemia affecting the apex, inferior wall, septum and anterior wall. 
Three patients were found to have perfusion defects (ischemia) in the apex and inferior and lateral walls. In two patients, evidence of ischemia was found in the inferior wall. Table 3 shows that the ejection fraction was above $50 \%$ in 6 patients, indicating normal overall left ventricular function. Mild to moderate reduction in ejection fraction was seen in two patients (EF 39-49\%), indicating reduction in ventricular function (Figure 2). There was severe reduction in ejection fraction in four patients $(\mathrm{EF}<35 \%)$, suggesting severe impairment of left ventricular function (Figure 3$)$. There was an increase in left ventricular end diastolic volume $(>120 \mathrm{~mL})$ in two patients, indicating diastolic dysfunction. There was an increase in left ventricular end systolic volume $(>70 \mathrm{~mL})$ in three patients, indicating systolic dysfunction and ischemic myopathy (Figure 4).

\begin{tabular}{lccc}
\multicolumn{2}{c}{ Table 2. Biological and clinical characteristics of subjects (ages between } & $15-35$ years). \\
\hline Characteristcs $(\mathrm{N}=32)$ & Male & Female & \\
\hline Gender & 22 & 10 & - \\
Family history of CAD & $31.25 \%$ & $0 \%$ & - \\
Diabetes (fasting plasma glucose $>126 \mathrm{mg} / \mathrm{dL})$ & $6.25 \%$ & $0 \%$ & $>0.05$ \\
Hypertension (blood pressure $>140 / 90 \mathrm{mmHg})$ & $28.12 \%$ & $0 \%$ & $<0.001$ \\
Smokers & $9.37 \%$ & $0 \%$ & $>0.001$ \\
Total cholesterol $(\mathrm{mM})$ & $6.3 \pm 0.9$ & $7.9 \pm 1.2$ & $>0.05$ \\
LDL- cholesterol $(\mathrm{mM})$ & $3.5 \pm 0.9$ & $5.1 \pm 0.9$ & $>0.05$ \\
\hline
\end{tabular}

\begin{tabular}{|c|c|c|c|c|}
\hline No. & $\mathrm{EF} \%$ & EDV & ESV & SV \\
\hline Subject 1 & 69 & 42 & 13 & 29 \\
\hline Subject 2 & 67 & 67 & 22 & 44 \\
\hline Subject 3 & 54 & 78 & 36 & 42 \\
\hline Subject 4 & 58 & 61 & 25 & 36 \\
\hline Subject 5 & 39 & 100 & 60 & 39 \\
\hline Subject 6 & 32 & 123 & 83 & 40 \\
\hline Subject 7 & 28 & 141 & 102 & 40 \\
\hline Subject 8 & 44 & 62 & 34 & 27 \\
\hline Subject 9 & 54 & 101 & 46 & 54 \\
\hline Subject 10 & 19 & - & - & - \\
\hline Subject 11 & 19 & 34 & 282 & 65 \\
\hline Subject 12 & 65 & - & - & - \\
\hline
\end{tabular}

$\overline{\mathrm{EF}}=$ ejection faction; $\mathrm{EDV}=$ end diastolic volume in $\mathrm{mL} ; \mathrm{ESV}=$ end systolic volume in $\mathrm{mL} ; \mathrm{SV}=\mathrm{stroke}$ volume in $\mathrm{mL}$.

\section{Mutational analysis of LDLR gene}

All samples were found negative for the five common mutations (W23X, W66G, W556S, 313+1G $>$ A, and 1846-1G $>$ A) by SSCP. After SSCP analysis, some variations were observed in exons 8 and 10, as shown in Figures 5 and 6.

\section{DNA sequencing}

A total of 12 reaction mixtures were sent for DNA sequencing. The data were aligned with a standard reference sequence, and the following variations were observed in various samples as shown in Table 4. One mutation and two polymorphisms were found in exon 8 and exon 10 . The mutation $1171 \mathrm{G}>\mathrm{A}$ is novel. No study has been reported to underline its effect. 

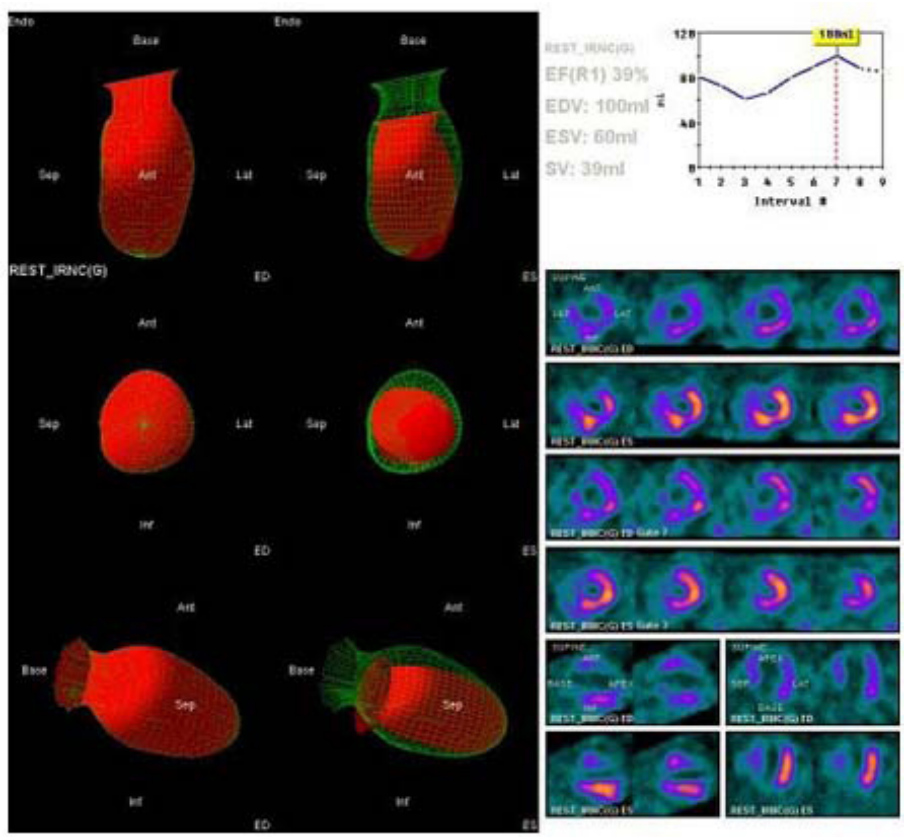

Figure 2. Perfusion SPECT images (at rest) showing an ejection fraction of $39 \%$ indicating mild to moderate reduction in ventricular function.

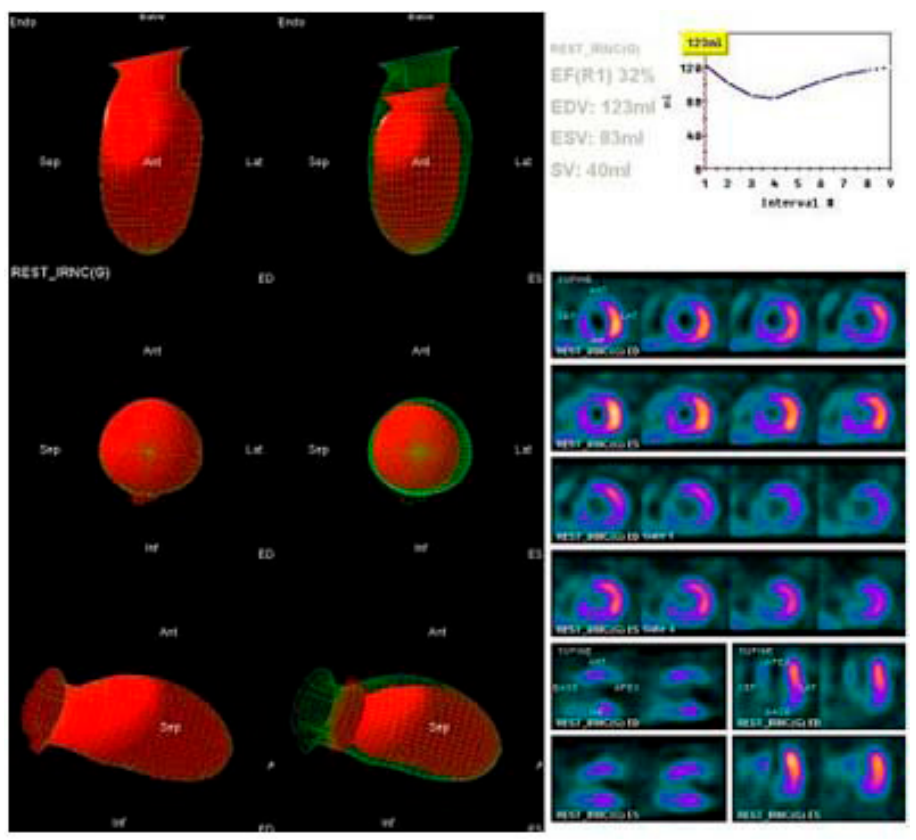

Figure 3. Perfusion SPECT images (at rest) showing an ejection fraction of $32 \%$ indicating severe reduction in ventricular function. 

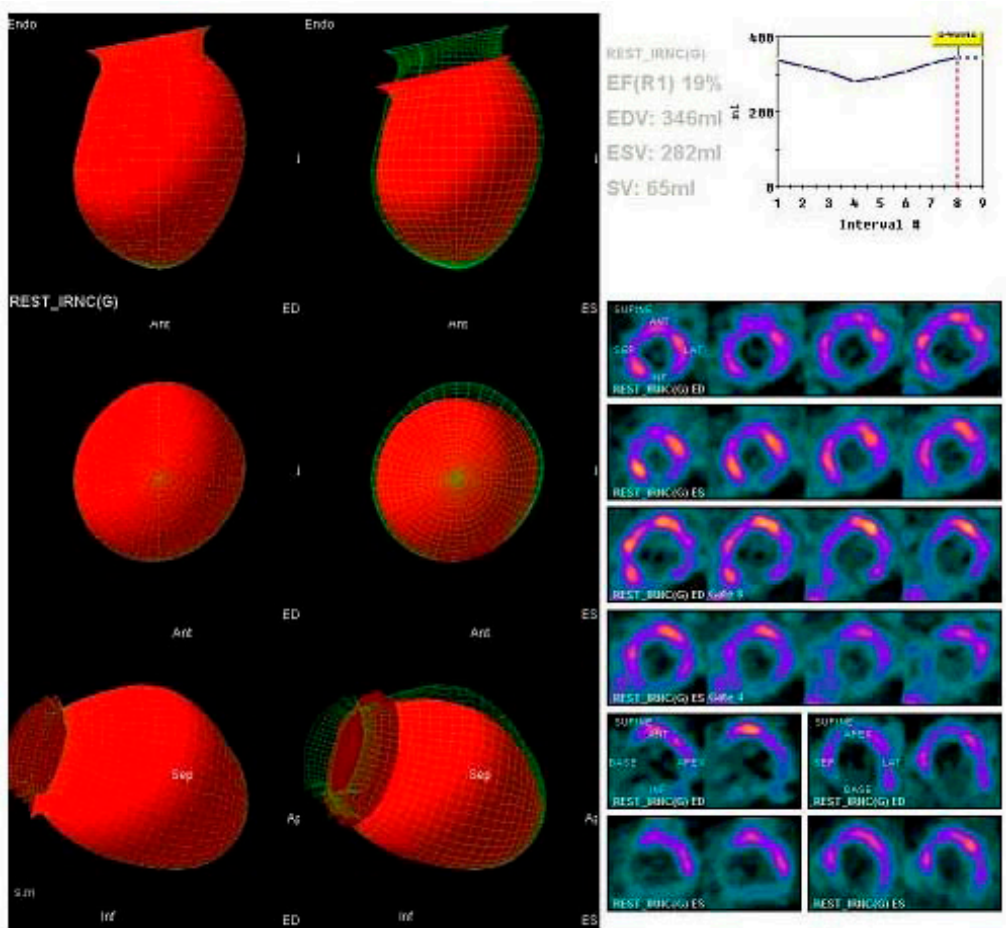

Figure 4. Perfusion SPECT images (at rest) showing an increase in left ventricular end diastolic volume (>120 mL) indicating diastolic dysfunction and an increase in left ventricular end systolic volume $(>70 \mathrm{~mL})$ indicating systolic dysfunction and ischemic myopathy.

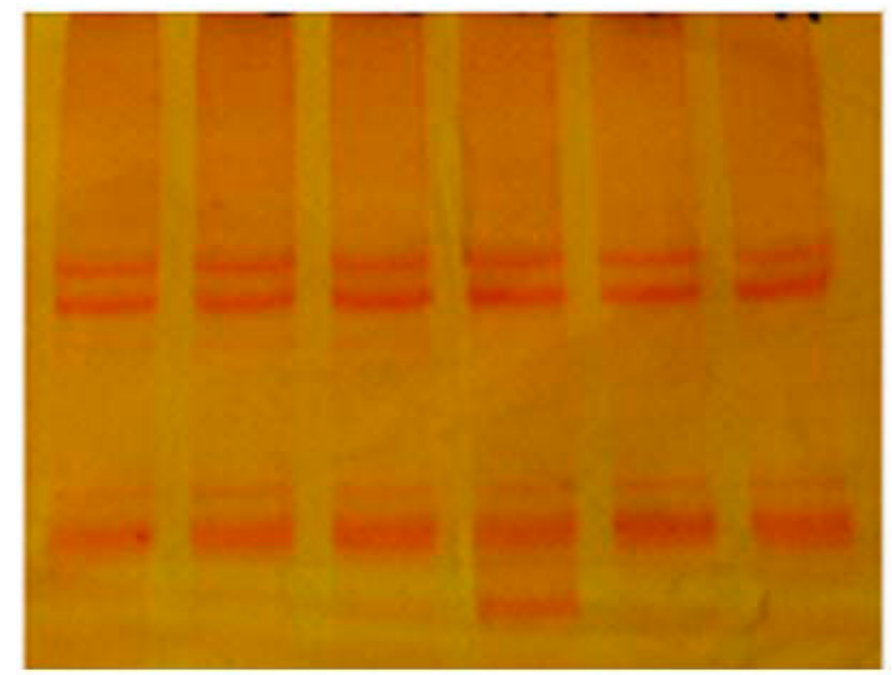

Figure 5. Mutational analysis of exon 8 by SSCP showing variations in a sample. twenty percent acrylamide gel was acquired by use of a voltage of $150 \mathrm{~V}$ and run time of $960 \mathrm{~min}$. It was visualized by silver stain. 


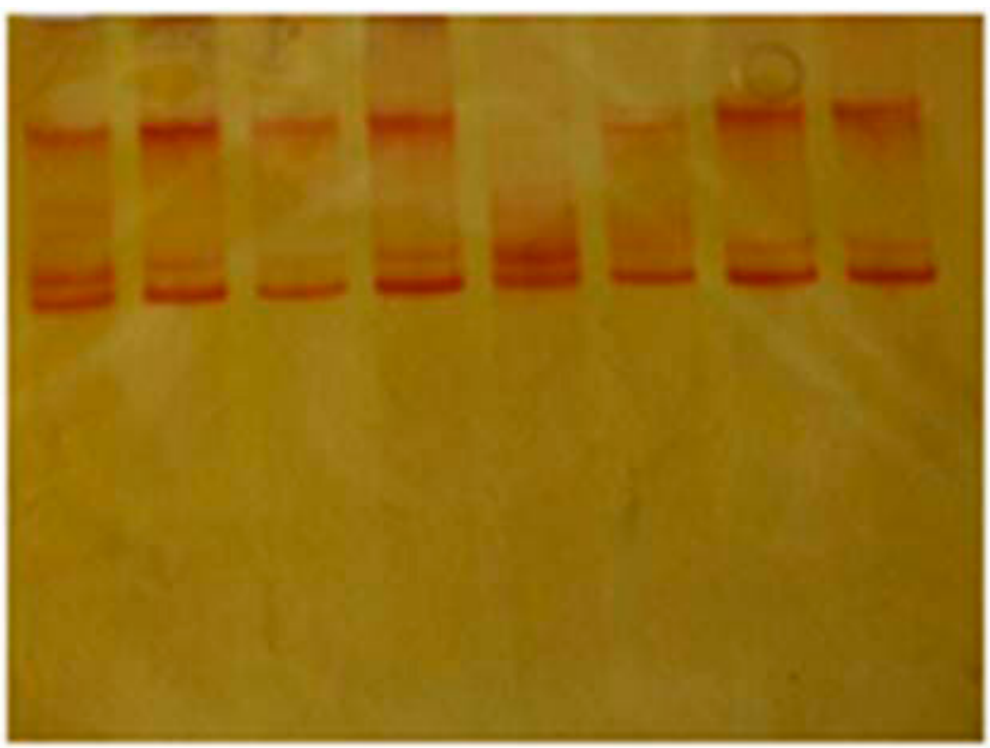

Figure 6. Mutational analysis of exon 10 by SSCP showing variations in a sample. twenty percent acrylamide gel was acquired by a voltage of $100 \mathrm{~V}$ and run time of $900 \mathrm{~min}$. It was visualized by silver stain.

\section{In silico analysis of mutations in LDLR gene}

In silico tools (SIFT, PolyPhen-2 and KD4v) were used to predict the effect of $1171 \mathrm{G}>\mathrm{A}$ mutation in exon 8 and the two polymorphisms $(1167 \mathrm{G}>\mathrm{A}$ and $1413 \mathrm{~A}>\mathrm{G})$ in exon 8 and 10 of the LDLR gene on LDLR structure and function (Table 5). SIFT (http://sift.jcvi. org/www/SIFT_enst_submit.html) predicts whether an amino acid substitution affects protein function. SIFT predicts the effect of a mutation based on the degree of conservation of amino acid residues in sequence alignments derived from closely related sequences. PolyPhen-2 is an automatic tool for prediction of possible impact of an amino acid substitution on the structure and function of a human protein. The prediction is based on a number of features such as the amino acid sequence and phylogenetic and structural information about the protein. PolyPhen-2 (http://genetics.bwh.harvard.edu/pph2/) is an automatic tool to predict the impact of an amino acid substitution on the structure and function of a human protein. The prediction is based on a number of features such as the amino acid sequence and phylogenetic and structural information. The KD4v (Comprehensible Knowledge Discovery System for Missense Variant) server provides physico-chemical properties of the phenotype of missense mutations.

Mutational analysis of the $L D L R$ gene was completed by the use of project HOPE using PDB-file 3m0c (Venselaar et al., 2010). Figure 7A shows the schematic structures of the original (left) and the mutant (right) amino acid. The mutant residue (Thr-391) is bigger than the wild-type residue (Ala-391). The wild-type residue is more hydrophobic than the mutant residue. The mutated residue is located very close to a residue that makes a disulfide bond. This disulfide bond itself is not mutated but it can be affected by a mutation in its vicinity (Figures 7B and 8). According to the PISA-database, this mutated residue is involved in 
a multimeric contact. The PISA-database contains protein assemblies that are highly likely to be biologically relevant. The mutation introduces a bigger residue at this position, which can disturb multimeric interactions. The mutation also introduces a less hydrophobic residue, which can also affect multimeric contacts.

Table 4. Mutations and polymorphisms found in $L D L R$ gene by DNA sequencing.
\begin{tabular}{llll}
\hline Sample 1 & Exon 8 & Mutation & $1171 \mathrm{G}>\mathrm{A}$ \\
Sample 2 & Exon 8 & Polymorphism & $1167 \mathrm{G}>\mathrm{A}$ \\
Sample 3 & Exon 10 & Polymorphism & $1413 \mathrm{~A}>\mathrm{G}$ \\
\hline
\end{tabular}

\begin{tabular}{|c|c|c|c|c|c|c|c|}
\hline Exon & $\begin{array}{l}\text { Mutation } \\
\text { observed }\end{array}$ & $\begin{array}{l}\text { Codon } \\
\text { change }\end{array}$ & $\begin{array}{l}\text { Change in } \\
\text { amino acid }\end{array}$ & Type of change & SIFT & PolyPhen-2 & $\begin{array}{l}\text { KD4v } \\
\text { (physico-chemical } \\
\text { properties) }\end{array}$ \\
\hline Exon 8 & $1171 \mathrm{G}>\mathrm{A}$ & $\mathrm{GCC} \rightarrow \mathrm{ACC}$ & $\begin{array}{l}\text { A-391 changes } \\
\text { to T-391 }\end{array}$ & Mutation & $\begin{array}{l}\text { Low confidence } \\
\text { prediction with } \\
\text { median conservation } \\
\text { above } 3.25\end{array}$ & $\begin{array}{l}\text { Mutation is predicted } \\
\text { to be benign with a very } \\
\text { low score of } 0.010\end{array}$ & $\begin{array}{l}\text { Size increases } \\
\text { Charge unchanged } \\
\text { Polarity increases } \\
\text { Hydrophobicity decreases } \\
\text { Disulfide bonds unchanged } \\
\text { Gly or Pro unchanged } \\
\text { Modification score } 14\end{array}$ \\
\hline Exon 8 & $1167 \mathrm{G}>\mathrm{A}$ & $\mathrm{ACG} \rightarrow \mathrm{ACA}$ & $\begin{array}{l}\text { No change in } \\
\text { amino acid (T-389) }\end{array}$ & Polymorphism & & & \\
\hline Exon 10 & $1413 \mathrm{~A}>\mathrm{G}$ & $\mathrm{AGA} \rightarrow \mathrm{AGG}$ & $\begin{array}{l}\text { No change in } \\
\text { amino acid (R-471) }\end{array}$ & Polymorphism & & & \\
\hline
\end{tabular}

(a)

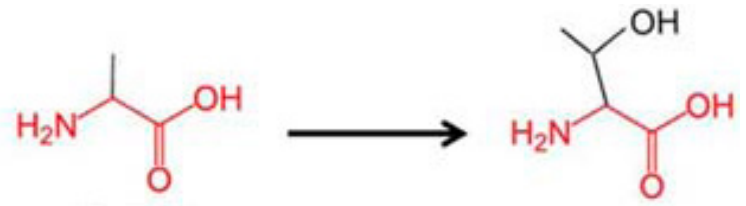

Ala-391

Thr-391

(b)

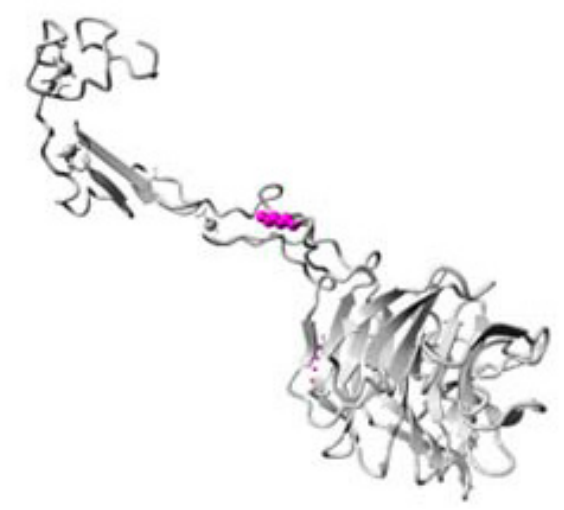

Figure 7. A. Schematic structures of the original (left) and the mutant (right) amino acid. B. Structure of LDLR presented as a ribbon-diagram. The protein is colored gray and the side chain of the mutation (A391T) is colored magenta and shown as small balls. 


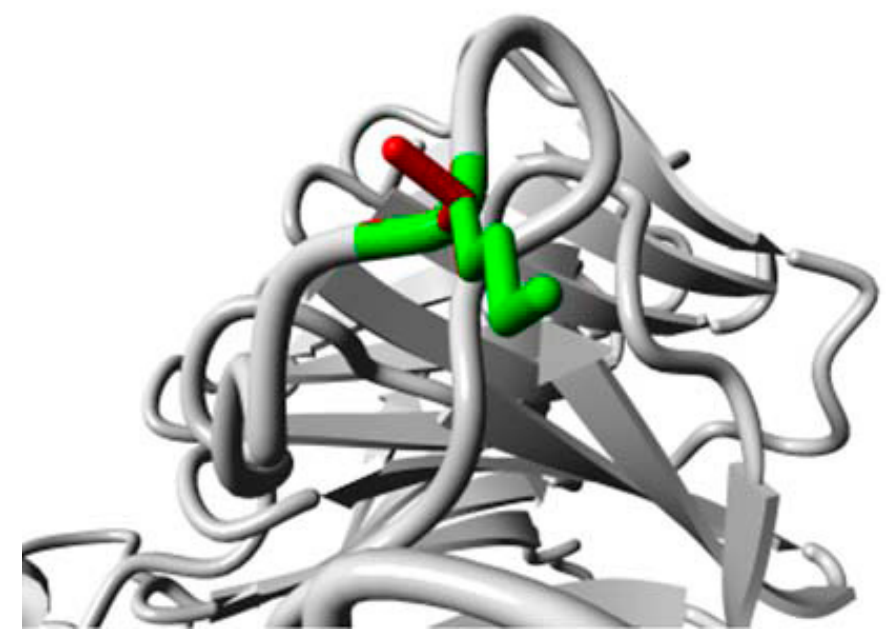

Figure 8. Close-up of the A391T mutation. The protein is colored gray, the side chains of both the wild-type and the mutant residue are shown and colored green and red, respectively.

\section{DISCUSSION}

In the present study, mutational analysis of $L D L R$ gene of 32 unrelated subjects yielded one mutation and 2 polymorphisms. None of the samples was positive for the five common mutations in the LDLR gene (W23X, W66G, W556S, 313+1G $>$ A, 1846-1G $>$ A). Compared with previously published papers (Peeters et al., 1997; Zakharova et al., 2005; Nissen et al., 2006; Campagna et al., 2008; Chmara et al., 2010; Kusters et al., 2011; Walus-Miarka et al., 2012), the number of mutations identified is less than before. The discrepancy between these results may be due to the screening method used, the sampling size used, and polygenic nature of FH. The SSCP screening method is not the ideal technique to identify every possible mutation. The subjects in previous studies were clinically diagnosed FH patients, whereas the subjects in our study were selected on the basis of high cholesterol levels. Mutations in other genes, such as the LDL receptor adaptor protein and adenosine triphosphate binding cassette transporters, can also contribute to the presence of a high level of cholesterol (Goldstein and Brown, 2001).

PCR-SSCP analysis has previously been used for mutational analysis of various genes (Hayashi and Yandell, 1993), including the LDL receptor gene (Loux et al., 1992; Gudnason et al., 1993; Leren et al., 1993). Many factors can influence the sensitivity of PCR-SSCP analysis, such as the length of the amplified fragments, the electrophoretic conditions, extent of cross-linking concentration of acrylamide and the presence or absence of glycerol (Hayashi and Yandell, 1993; Sheffield et al., 1993). There have been reports about some discrepancies in the sensitivity of this technique. Detection rates in different studies including the LDLR gene can be as low as 50\% (Hayashi and Yandell, 1993). In general, the sensitivity of the method is very high when appropriate conditions are chosen (Leren et al., 1993; Sheffield et al., 1993). Sensitivity is especially highest when the PCR fragment is smaller than $200-300$ bp (Hayashi and Yandell, 1993). The position of a single base substitution seems to be more important than the type of mutation (transversion versus transition) in determining whether a 
mutation is detected (Sheffield et al., 1993). The sensitivity of a mutation detection method has usually been evaluated by the rate of detection of already known mutations. However, a more definitive evaluation of the sensitivity of such a mutation screening method is to compare the rate of detected sequence variations with the results of DNA sequencing of the same amplified fragments, assuming of course that the sequencing method used actually is capable of detecting all sequence variations.

DNA sequencing of the samples yielded one mutation $(1171 \mathrm{G}>\mathrm{A})$ in exon 8 and two polymorphisms $(1167 \mathrm{G}>\mathrm{A}$ and $1413 \mathrm{~A}>\mathrm{G})$ in exons 8 and 10 . The mutation $1171 \mathrm{G}>\mathrm{A}$ is totally new. This mutation results in the conversion of Ala-391 to Thr-391. In silico tools showed that Ala-391 is located in a domain which is "EGF 2-like" or "calcium-binding" (Figure 9). The $1171 \mathrm{G}>$ A mutation introduces Thr-391 at this position. The threonine residue has different properties, which can disturb this domain and abolish its function.

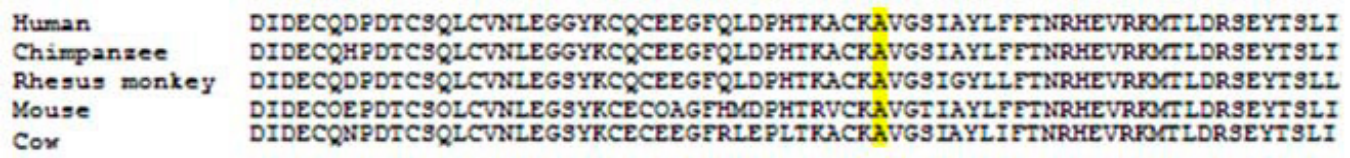

Figure 9. Protein sequence alignment showing the location of conserved amino acid Ala-391 in "EGF 2-like" or "calcium-binding" domain of LDLR.

\section{CONCLUSION}

This project identified a single mutation and two polymorphisms in 32 unrelated patients. Although this incidence rate is too low to implicate the role of a mutation, rapid RFLP detection methods may provide a practical direction and approach for future studies. For patients suffering from systolic dysfunction, the identification of gene defects is of prognostic value, making early detection, optimal treatment approaches, and a reduction in the risk factors associated with coronary artery disease highly possible.

\section{REFERENCES}

Abel LL, Levy BB, Brodie BB and Kendall FE (1952). A simplified method for the estimation of total cholesterol in serum and demonstration of its specificity. J. Biol. Chem. 195: 357-366.

Austin MA, Hutter CM, Zimmern RL and Humphries SE (2004). Genetic causes of monogenic heterozygous familial hypercholesterolemia: a HuGE prevalence review. Am. J. Epidemiol. 160: 407-420.

Bachorik PS (2000). Measurement of Low-Density Lipoprotein Cholesterol. In: Handbook of Lipoprotein Testing. (Rifai N, Warnick GR and Dominczak MH, eds.). AACC Press, Washington.

Campagna F, Martino F, Bifolco M, Montali A, et al. (2008). Detection of familial hypercholesterolemia in a cohort of children with hypercholesterolemia: results of a family and DNA-based screening. Atherosclerosis 196: 356-364.

Chmara M, Wasag B, Zuk M, Kubalska J, et al. (2010). Molecular characterization of Polish patients with familial hypercholesterolemia: novel and recurrent LDLR mutations. J. Appl. Genet. 51: 95-106.

Davignon J and Ganz P (2004). Role of endothelial dysfunction in atherosclerosis. Circulation 109: III27-III32.

Francke U, Brown MS and Goldstein JL (1984). Assignment of the human gene for the low density lipoprotein receptor to chromosome 19: synteny of a receptor, a ligand, and a genetic disease. Proc. Natl. Acad. Sci. U. S. A. 81: 2826-2830.

Goldstein JL, Hobbs HH and Brown MS (1995). Familial Hypercholesterolemia. In: The Metabolic Bases of Inherited Disease. (Scriver CR, Beaudet AL, Sly WS and Valle D, eds.). McGraw-Hill, New York. 1981-2030.

Goldstein JL and Brown MS (2001). Molecular medicine. The cholesterol quartet. Science 292: 1310-1312.

Gudnason V, Mak YT, Betteridge J, McCarthy SN, et al. (1993). Use of the single-strand conformational polymorphism 
method to detect recurrent and novel mutations in the low-density lipoprotein receptor gene in patients with familial hypercholesterolaemia: detection of a novel mutation Asp200 $\rightarrow$ Gly. Clin. Investig. 71: 331-337.

Hayashi K and Yandell DW (1993). How sensitive is PCR-SSCP? Hum. Mutat. 2: 338-346.

Hobbs HH, Brown MS and Goldstein JL (1992). Molecular genetics of the LDL receptor gene in familial hypercholesterolemia. Hum. Mutat. 1: 445-466.

Khan NR and Mallick IA (1992). Economic situation in Pakistan's, National Health Survey of Pakistan. Pak. J. Med. Res. 31: $282-8$.

Kusters DM, Huijgen R, Defesche JC, Vissers MN, et al. (2011). Founder mutations in the Netherlands: geographical distribution of the most prevalent mutations in the low-density lipoprotein receptor and apolipoprotein B genes. Neth. Heart J. 19: 175-182.

Leren TP, Solberg K, Rodningen OK, Ose L, et al. (1993). Evaluation of running conditions for SSCP analysis: application of SSCP for detection of point mutations in the LDL receptor gene. PCR Methods Appl. 3: 159-162.

Lindgren V, Luskey KL, Russell DW and Francke U (1985). Human genes involved in cholesterol metabolism: chromosomal mapping of the loci for the low density lipoprotein receptor and 3-hydroxy-3-methylglutaryl-coenzyme A reductase with cDNA probes. Proc. Natl. Acad. Sci. U. S. A. 82: 8567-8571.

Loux N, Saint-Jore B, Collod G, Dairou F, et al. (1992). Screening for new mutations in the LDL receptor gene in seven French familial hypercholesterolemia families by the single strand conformation polymorphism method. Hum. Mutat. 1: 325-332.

Maton A, Roshan L, Hopkins J, McLaughlin CW, et al. (1993). Human Biology and Health. Prentice Hall, Englewood Cliffs.

Michelena HI and VanDecker WA (2005). Radionuclide-based insights into the pathophysiology of ischemic heart disease: beyond diagnosis. J. Investig. Med. 53: 176-191.

Nissen PH, Damgaard D, Stenderup A, Nielsen GG, et al. (2006). Genomic characterization of five deletions in the LDL receptor gene in Danish Familial hypercholesterolemic subjects. BMC Med. Genet. 7: 55.

Peeters AV, Van Gaal LF, du Plessis L, Lombardi MP, et al. (1997). Mutational and genetic origin of LDL receptor gene mutations detected in both Belgian and Dutch familial hypercholesterolemics. Hum. Genet. 100: 266-270.

Samad A, Sahibzada WA and Mattu A (1992). Risk factor analysis in a random population of 4 cities in Pakistan. Pak. J. Cardiol. 3: 7-14.

Sheffield VC, Beck JS, Kwitek AE, Sandstrom DW, et al. (1993). The sensitivity of single-strand conformation polymorphism analysis for the detection of single base substitutions. Genomics 16: 325-332.

Tsouli SG, Kiortsis DN, Argyropoulou MI, Mikhailidis DP, et al. (2005). Pathogenesis, detection and treatment of Achilles tendon xanthomas. Eur. J. Clin. Invest. 35: 236-244.

Venselaar H, Te Beek TA, Kuipers RK, Hekkelman ML, et al. (2010). Protein structure analysis of mutations causing inheritable diseases. An e-Science approach with life scientist friendly interfaces. BMC Bioinformatics 11: 548.

Walus-Miarka M, Sanak M, Idzior-Walus B, Miarka P, et al. (2012). A novel mutation (Cys308Phe) of the LDL receptor gene in families from the South-Eastern part of Poland. Mol. Biol. Rep. 39: 5181-5186.

Yamamoto T, Davis CG, Brown MS, Schneider WJ, et al. (1984). The human LDL receptor: a cysteine-rich protein with multiple Alu sequences in its mRNA. Cell 39: 27-38.

Zakharova FM, Damgaard D, Mandelshtam MY, Golubkov VI, et al. (2005). Familial hypercholesterolemia in StPetersburg: the known and novel mutations found in the low density lipoprotein receptor gene in Russia. BMC Med. Genet. 6: 6. 